\title{
Effects of substrate water potential in root growth of Agave salmiana Otto ex Salm-Dyck seedlings
}

\author{
CECILIA B PEÑA-VALDIVIA ${ }^{1}$ and ADRIANA B SÁNCHEZ-URDANETA ${ }^{2}$
}

${ }^{1}$ Botánica, Colegio de Postgraduados, Km 35.5 Carretera México-Texcoco, Montecillo, México. 56230.
${ }^{2}$ Facultad de Agronomía, Universidad del Zulia, Av. Ziruma, Maracaibo, Venezuela.

\begin{abstract}
The objective of this study was to test the hypothesis that root of maguey (Agave salmiana Otto ex SalmDyck) seedlings reacts during the first $24 \mathrm{~h}$ to low substrate water potential $\left(\Psi_{\mathrm{W}}\right)$, by anatomical modifications. Three- $4 \mathrm{~cm}$ root length seedlings were planted in vermiculite for $24 \mathrm{~h}$ at $\Psi_{\mathrm{W}}$ between -0.03 and $-2.35 \mathrm{MPa}$. Root dimensions, proline content and anatomy were evaluated. Substrate $\Psi_{\mathrm{W}}$ between -0.65 and $2.35 \mathrm{MPa}$ did not significantly affect longitudinal root growth. However, proline content significantly increased from 1.6 to $2.1 \mu$ moles $\mathrm{mg}^{-1}$. Significant reductions of transverse root area (41\%), thickness of mucilage covering the epidermis (47\%), thickness of epidermis (between 15 and $46 \%$ ), area of the parenchyma (between 35 and $41 \%$ ) and number of vessels (up to $28 \%$ ) were observed with $\Psi_{\mathrm{W}}$ of -2.35 $\mathrm{MPa}$. In contrast, thickness of xylem wall, diameter of xylem vessels and the number of cells of the cortex of the differentiation root region significantly increased $(64,17$, and $97 \%$, respectively). The anatomical changes associated with low substrate $\Psi_{\mathrm{W}}$ indicate a net increase of root apoplatic paths; structures involved in water conduction increased their diameter under low substrate $\Psi_{\mathrm{W}}$ conditions and anatomical changes occurred during the first $24 \mathrm{~h}$ of water stress.
\end{abstract}

Key terms: Maguey, proline, root anatomy, root growth, water deficit, water stress.

\section{INTRODUCTION}

For the last 20 years evidence has shown that roots are more sensitive to small changes in soil water content than to any change in shoot water relations. This early warning system triggers several signals that are sent through the vascular system to regulate growth and gas exchange (Davies and Zhang, 1991). This kind of feedback reaction involves an early detection of environmental changes which may help the survival of plants (Passioura, 2002).

Physiological and biochemical changes as a result of water deficit have been widely described in annual species with C3 (Phaseolus spp., Nicotiana spp., Vicia faba L., Allium cepa L., Lycopersicum esculentum Miller, Cicer arietinum L., Glycine max (L.) Merr.) and C4 (Oryza sativa L., and Zea mays L., Sorghum bicolor (L.) Moench. Andropogon gayanus Kunth and Brachiaria mutica (Fonsk.) Stapf) photosynthetic metabolism. These changes are mainly associated with gas exchange, photosynthesis, accumulation and degradation of metabolites, alterations of cellular membranes and some enzymatic activities in leaves (Hare and Cress, 1997; Steudle, 2000; Wu and Cosgrove, 2000; Yin et al., 2004; Zlatev, 2005). However, plants with crassulacean acid metabolism (CAM) have a partially physiological description. The physiological root reactions to water availability in soil are diverse; however, metabolic factors controlling root survival in such conditions are only partially known due to the experimental difficulties in accessing intact roots (Huang and Gao, 2000). 
Several studies have revealed that in species like Betula ermanii, $B$. maximowicziana, $B$. platyphylla, $P$. vulgaris L., and Triticcum aestivum soil water deficit increases the root/shoot ratio due to an increase of root growth and an inhibition of shoot growth (Asseng et al., 1998; Koike et al., 2003). Experiments conducted under laboratory conditions have demonstrated that maize root continues growing at substrates with a water potential $\left(\Psi_{\mathrm{W}}\right)$ of $-1.6 \mathrm{MPa}$, while shoot growth is totally inhibited at -0.8 MPa (Sharp et al., 1988 and 1990). The root response seems to have an ecological significance when the plant grows under a water deficit. Therefore, shoot growth inhibition helps to save water and to keep tissues hydrated, without significant reduction of plant metabolism. In addition, root growth maintenance improves water extraction from soil at deeper layers.

Agave salmiana as a CAM plant (Gibson and Nobel, 1986) fixes $\mathrm{CO}_{2}$ during the night as malic acid. This acid is then stored in the vacuole and thereafter, during the day, is released from the vacuole and decarboxylated. The resulting $\mathrm{CO}_{2}$ is then assimilated via the Calvin cycle. CAM plants are resistant to a xerothermic environment, with extremely dry soil and air, high salt content in the soil and extreme temperatures during the summer and winter. There is convincing evidence that roots of adult Agavaceae plants survive under extremely dry conditions $\left(\Psi_{\mathrm{W}}\right.$ as low as $-3.2 \mathrm{MPa}$ for 30 days) (Nobel et al., 1990; North and Nobel, 1995; Dubrovsky, 1997). Therefore, the roots of $A$. salmiana are an interesting model to study the physiological and anatomical changes involved in drought tolerance occurring in short periods. It is well known that CAM plants are tolerant to water deficit, but root changes and physiological mechanisms under extreme soil $\Psi_{\mathrm{W}}$ are only partially known. The objective of this study was to test the hypothesis that root of maguey (Agave salmiana Otto ex Salm-Dyck) seedlings react during the first $24 \mathrm{~h}$ to low substrate water potential $\left(\Psi_{\mathrm{W}}\right)$, by anatomical modifications.
MATERIALS AND METHODS

\section{Genetic Material}

Seeds of $A$. salmiana collected in the locality of "Minera las Cuevas" (21 ${ }^{\circ}$ 56" Lat. N, $100^{\circ} 35^{\prime}$ Long. W, and 1890 masl), Zaragoza, San Luis Potosi, Mexico, were used in this study. The climate in this locality is arid, with the summer rainy season divided by a short dry season, and followed by a long dry season; daily temperatures changes can be up to $35^{\circ} \mathrm{C}$ and annual mean temperature fluctuates between 12 and $18^{\circ} \mathrm{C}$ (García, 1988). This seed lot had high percentage of germination (85\%), according to Peña-Valdivia et al. (2006).

\section{Experimental}

Seeds were mechanically scarified (by making $1 \mathrm{~mm}$ deep incision in the marginal region using a scalpel) and soaked in water at $24 \pm 2^{\circ} \mathrm{C}$ for $24 \mathrm{~h}$. The seeds were then germinated at $25 \pm 1^{\circ} \mathrm{C}$ in the dark between pleated paper (Ellis et al., 1985) and $35^{\circ}$ inclination. Synchronic germination was reached after $72 \mathrm{~h}$, and seedlings with short hypocotyl $(3 \mathrm{~cm})$ and $35 \mathrm{~mm}$ mean root length were obtained after $144 \mathrm{~h}$. Then seedlings were transplanted into polyvinylchloride (PVC) tubes (40 and $100 \mathrm{~mm}$ inside diameter and length, respectively) filled with vermiculite at different $\Psi_{\mathrm{W}}$ in a dark room. Each PVC tube was covered at both ends with a piece of black polyethylene fixed with elastic bands to keep the vermiculite at a constant $\Psi_{\mathrm{W}}$. The containers were maintained in the dark at $25 \pm 1^{\circ} \mathrm{C}$ for $24 \mathrm{~h}$, thereafter roots were harvested.

Different vermiculite $\Psi_{\mathrm{W}}(-0.03,-0.65$, -1.48 and $-2.35 \mathrm{MPa}$ ) were obtained by mixing dry vermiculite with $100,10,8$ and 6 parts of distilled water (weight: volume) in polyethylene bags $48 \mathrm{~h}$ before starting the experiment. Subsequently, vermiculite $\Psi_{\mathrm{W}}$ was determined by incubating a sample of vermiculite in psychrometric chambers (Wescon C-52, Inc, Utha, USA) for $4 \mathrm{~h}$. Vermiculite $\Psi_{\mathrm{W}}$ was determined connecting the chambers to a 
microvoltmeter (Wescon HR-33T, Inc, Utha, USA) operated in the dew point mode. Longitudinal root growth, anatomical root characteristics, turgor pressure $(\Psi \mathrm{t})$, fresh and dry weight, and root proline content were evaluated.

Total root length was estimated using a calliper scaled in $1.0 \mathrm{~mm}$ units and 0.05 $\mathrm{mm}$ vernier (accuracy to $\pm 0.01 \mathrm{~mm}$ ); fresh and dry weight was quantified in an analytic balance (Scientech, with $0.0001 \mathrm{~g}$ precision). Root dry mater and proline were determined in freeze-dried samples; samples were previously wrapped in aluminium foil, frozen in liquid nitrogen, and then freeze-dried for $72 \mathrm{~h}$. Proline content was quantified using a colorimetric method and a calibration curve with a maximum concentration of 1000 nmols of proline per mL (Bates et al., 1973).

Roots were sampled and placed in cups of thermocouple-psychrometers connected to a dew point micro-voltmeter (Wescor HR-33T, Inc., Utah, USA), after $4 \mathrm{~h}$ of thermal and water vapour equilibrium the $\Psi_{\mathrm{W}}$ was determined. The same root samples were used for determining solute potential $\left(\Psi_{\mathrm{S}}\right)$ after they had been frozen in liquid nitrogen. Turgor potential $(\Psi \tau)$ was calculated as the difference between $\Psi_{\mathrm{W}}$ and $\Psi_{\mathrm{S}}$.

Anatomical characteristics were evaluated in cross-sectional segments belonging to the first centimetre of the root from the apex, including cell division and differentiation root regions. Tissue was fixed in an acetic acid: formaldehyde: ethanol: water solution (FAA, 5: 10: 52: 33 ), in a 10: 1 (w: v) fixer: sample ratio, for 4 to $6 \mathrm{~d}$, and then dehydrated with butyl alcohol, followed by embedding with paraffin, sectioning into $10 \mu \mathrm{m}$ ribbons and mounting on glass slides with chrome adhesive. Staining was done using a safranine-fast-green system, according to Johansen (cite by Sánchez, 2000). The dimensions and numbers of anatomical structures were obtained with inverted microscopy (ZEISS, Axiovert 25), equipped with a video chamber (SONY SSC-DC54), and the analysis was made with the software Image Tool 3.0 for personal computers (Wilcox et al., 2002).
The effect of $24 \mathrm{~h}$ of re-hydration on root growth was evaluated; $50 \mathrm{~mL}$ of water were added to each container that had substrate $\Psi_{\mathrm{W}}$ between -0.65 and $-2.35 \mathrm{MPa}$, and $24 \mathrm{~h}$ after watering root growth was evaluated.

\section{Experimental Design and Statistical Analysis}

The experiment was conducted according to a completely random design with four replicates. The treatments corresponded to four substrate $\Psi_{\mathrm{W}}(-0.03,-0.65,-1.48 \mathrm{y}-$ $2.35 \mathrm{MPa})$ and each experimental unit included 10 roots. Data were analysed using the General Linear Model Procedures of SAS. Differences among treatments were considered to be significant at $\mathrm{P}<0.05$. Means were compared using Tukey's method. Interaction effects among the anatomical characters between both root regions were analysed with the LSMEANS test. Also a Pearson correlation analysis was performed dividing the data in two treatments: $\Psi_{\mathrm{W}}$ of $-0.03 \mathrm{MPa}$, and $\Psi_{\mathrm{W}}$ of $0.65,-1.48$ and $-2.35 \mathrm{MPa}$. Graphic representation of the data and the selection of the best mathematical adjustment were performed with Sigma Plot software of Jandel Scientific (version 7.1) for personal computer.

\section{RESULTS AND DISCUSSION}

\section{Total Root Growth}

The hypocotyl length of seedlings (144 h old) was similar to root length $(33 \mathrm{~mm})$; but, fresh and dry biomass was five times higher in hypocotyl than in root. Seedlings continued growing after transplantation in vermiculite, mostly at $\Psi_{\mathrm{W}}$ of $-0.03 \mathrm{MPa}$. By this time (168 $\mathrm{h}$ after germination started) seedling growth was partially affected by vermiculite $\Psi_{\mathrm{W}}$ between -0.65 and -2.35 $\mathrm{MPa}$ compared to $-0.03 \mathrm{MPa}$; thus, hypocotyl length diminished significantly (6.1 $\mathrm{mm}$, equivalent to $17 \%$ ) even though root length was not affected. The hypocotyl reacted in part differently to low $\Psi_{\mathrm{W}}$ than did the root, this reaction became visible in 
a relatively brief time, and in the following development stages root growth was also affected, as the root is partially dependent on hypocotyl reserves (Smith and Snedaker, 2000). As well, the percentage of hypocotyl and dry root biomass increased significantly ( 7 and $13 \%$ on average, respectively) in substrate $\Psi_{\mathrm{W}}$ lower than $-0.03 \mathrm{MPa}$ (Fig. 1). All these results indicated that substrate $\Psi_{\mathrm{W}}$ between -0.65 and $-2.35 \mathrm{MPa}$ only partially affected seedling root growth of $A$. salmiana. Substrate $\Psi_{\mathrm{W}}$ of $-1.5 \mathrm{MPa}$ has been reported as a growth inhibitor of maize, soybean, rice and cucumber (Cucumis sativus L.) roots (Spollen et al., 1993). The results of the present work also indicate that "maguey" seedlings growing in a substrate containing 6 and $10 \%$ humidity $(-2.35$ and $-0.65 \mathrm{MPa}$, respectively) had enough water in the roots to continue growing (Fig. 1). As well, after re-hydration the roots continued growing.

\section{Proline}

Proline in the maguey roots increased significantly (almost $100 \%$, from 1.6 to 2.1 $\mathrm{mmol} \cdot \mathrm{mg}^{-1}$ of dry weight) when seedlings were maintained in vermiculite at $\Psi_{\mathrm{w}}$ of 1.48 and -2.35 MPa (Fig. 2 B). Proline root accumulation, as a reaction to water deficit and low substrate $\Psi_{\mathrm{W}}$, has been observed in several species, like maize (Raymond and Smirnoff, 2002; Sánchez-Urdaneta et al., 2005), rye and wheat (Albarrán, 2004), domesticated and wild $P$. vulgaris L. (Sánchez-Urdaneta et al., 2003; Khadri et al., 2007), and olive trees (Olea europaea L.) (Sofo et al., 2004). Proline accumulation in leaves and roots has been interpreted as a result of an imbalance in plant metabolism, but evidence indicate that proline can benefit a stressed plant by osmotic adjustment (Sofo et al., 2004; Xing Yuan et al., 2004). Proline has been classified as an osmoregulator in maintaining growth under water deficit and even after re-hydration (Prechamandra et al., 1992; Sánchez-Urdaneta et al., 2003 and 2004).

Proline increased in Agave root seedlings in the present study, but contrasted to other species that involves a several-fold increase in the net rate of proline deposition as a water-stress reaction (Sánchez-Urdaneta et al., 2005). However, the primary contribution to osmotic adjustment can be increases in factors other than proline osmoticum deposition (i.e. sugars, inorganic ions and several amino acids); besides osmotic adjustment along seedling root could be heterogeneous. In contrast to the basal root region of the growth zone of water-stressed maize roots, in the few apical millimeters this amino acid contributes up to $50 \%$ of osmotic adjustment (Sharp et al., 2004). In the present study complete $35 \mathrm{~mm}$ long root of seedlings were used for proline quantification.

The characteristics and mechanisms of "maguey" root that allow growth under drought conditions are unknown, but they could be related to the chemical composition of tissue. It is well known that high solute accumulation maintains tissue water absorption, tissue turgor and therefore growth in several species (Saito and Terashima, 2004; Vicré et al., 2004; Touchette, 2006; Bacelar et al., 2007). In the present study, substrate $\Psi_{\mathrm{W}}$ lower than $0.03 \mathrm{MPa}$ significantly increased $\operatorname{root} \Psi_{\tau}$ (from 0.08 to $0.15 \mathrm{MPa}$; Fig. 2A) and an inverse relationship between them $\left(r^{2}=0.9926\right.$ and $\left.n=40\right)$ existed. Turgor maintenance is necessary in plant cells to promote and modulate growth velocity. Loss of turgor pressure could result in total growth inhibition and eventually cell death. Osmotic adjustment is the main plant adaptation to maintain turgor when plants are under conditions of water stress or others kinds of stress (Saito and Terashima, 2004).

\section{Growth of Anatomical Structures}

Low substrate $\Psi_{\mathrm{w}}(-0.65$ and $-2.35 \mathrm{MPa})$ significantly reduced transverse root area (up to $41 \%$ ), thickness of the mucilage covering the epidermis (up to $47 \%$ ), epidermis thickness (up to $46 \%$ ), cell area of cortex (parenchyma; up to $41 \%$ ) and the number of xylem vessels (up to $28 \%$ ). In contrast, a sharp linear increase in the number of cortex cells, xylem vessel diameter (up to $17 \%$ ) and xylem wall thickness (64\%) was observed (Fig. 2 and 3). 

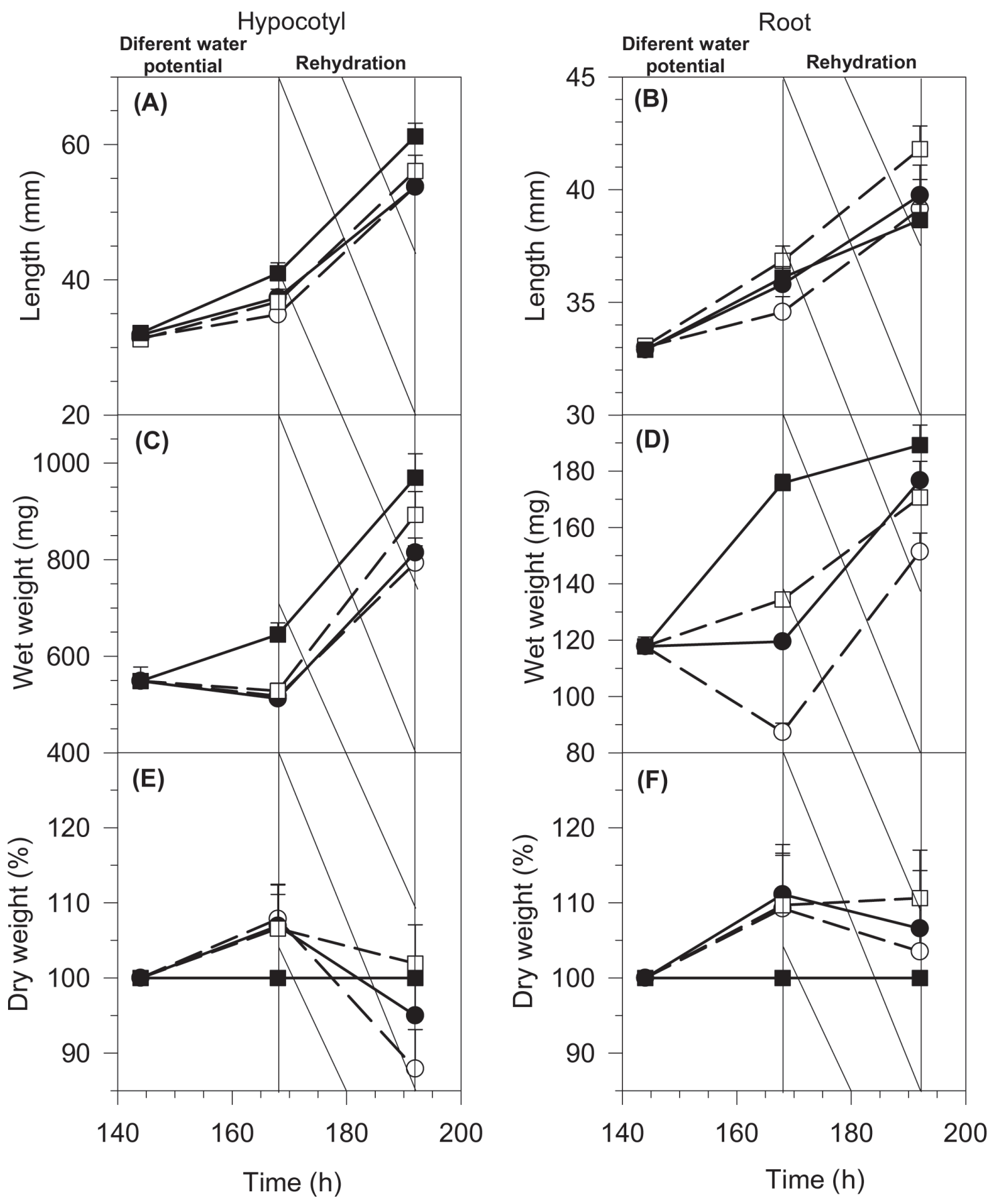

Figure 1: Hypocotyls and root growth of Agave salmiana Otto ex Salm-Dyck seedlings in vermiculite at different water potential: $-0.03 \mathrm{MPa}: \mathbf{\square},-0.65(\square),-1.48(\bullet)$ and $-2.35 \mathrm{MPa}(\mathrm{O})$ after $144 \mathrm{~h}$ of germination. Each point represent the average of four replicates $(n=40)+$ standard error. 


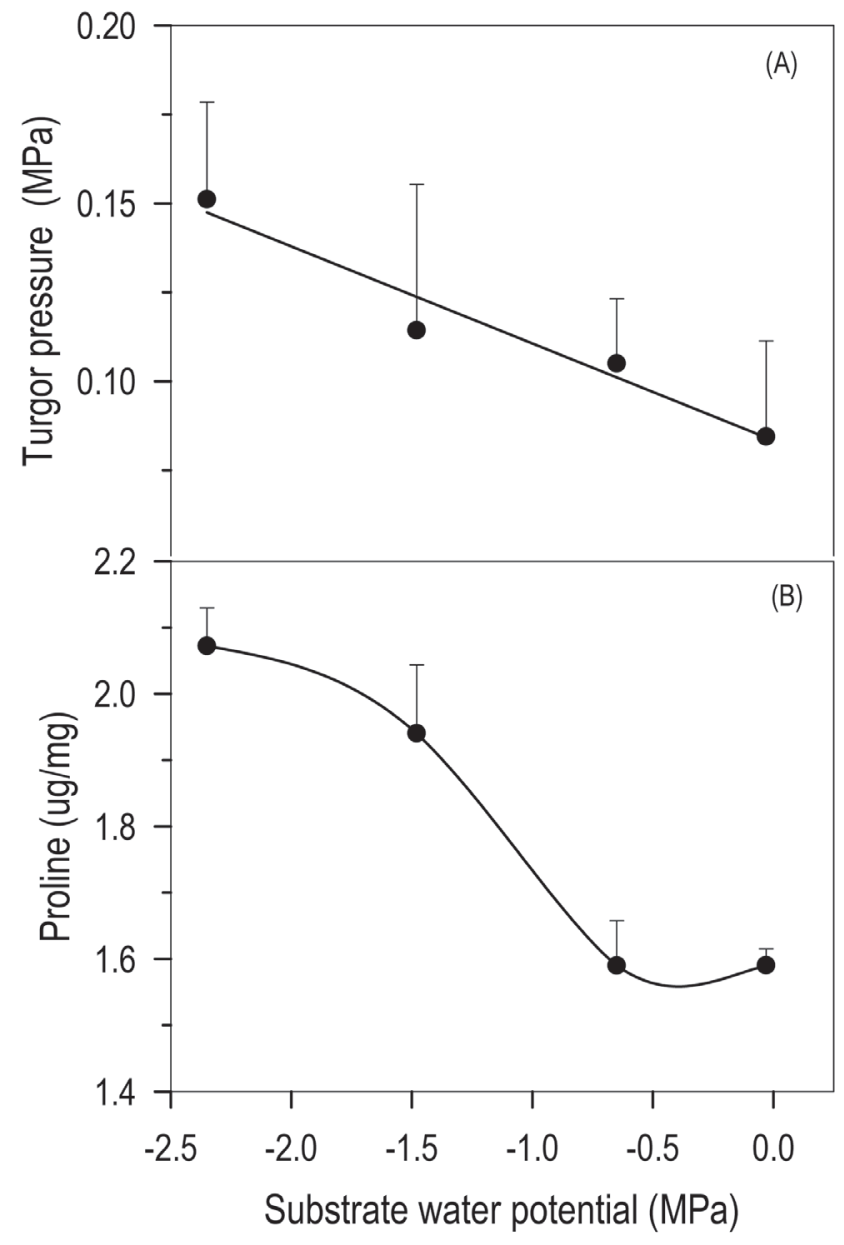

Figure 2: Effects of substrate water potential on turgor pressure (A) and proline content (B) of Agave salmiana Otto ex Salm-Dyck root seedlings. Each point represents the average of 10 replicates + standard error.

Longitudinal root growth of 144-168 h old seedlings, growing in vermiculite at $\Psi_{\mathrm{w}}$ of $-0.03 \mathrm{MPa}$, was correlated significantly and positively with the area of parenchyma cells $(\mathrm{r}=0.459, \mathrm{P}<0.021$ and $\mathrm{n}=25)$ of the root cross section, but under lower vermiculite $\Psi_{\mathrm{W}}$ this relationship was not significant $(\mathrm{r}=-0.025, \mathrm{P}<0.810$ and $\mathrm{n}=91)$. Xylem root morphology and anatomy are relevant for water conduction along the seedling and the entire plant tissue; however, in the present study neither number and diameter of xylem vessels nor xylem wall thickness correlated significantly with any growth variable of seedlings growing at $\Psi_{\mathrm{W}}$ of $-0.03 \mathrm{MPa}$.

The effect of water deficit in some anatomical root characteristics has already been documented. Seedlings of drought tolerant rice genotypes had thicker roots with broader xylem vessels than the susceptible genotype; but, water stress did not significantly affect the root and xylem thickness (Umayal et al., 2001). Root exodermis of Agave become suberized and the endodermis and the cortex become thicker due to drought (North and Nobel, 1995; Bobich and Gretchen, 2009). The results of the present study partially agreed with those observed in maize, where the cortical cells shrank and lost shape when relative water content ( $\mathrm{RWC}$ ) reached values of 0.5 , and cells collapsed when RWC was 0.3 (Facette et al., 1999). Although there are remarkable differences in magnitude, this tendency was similar to 


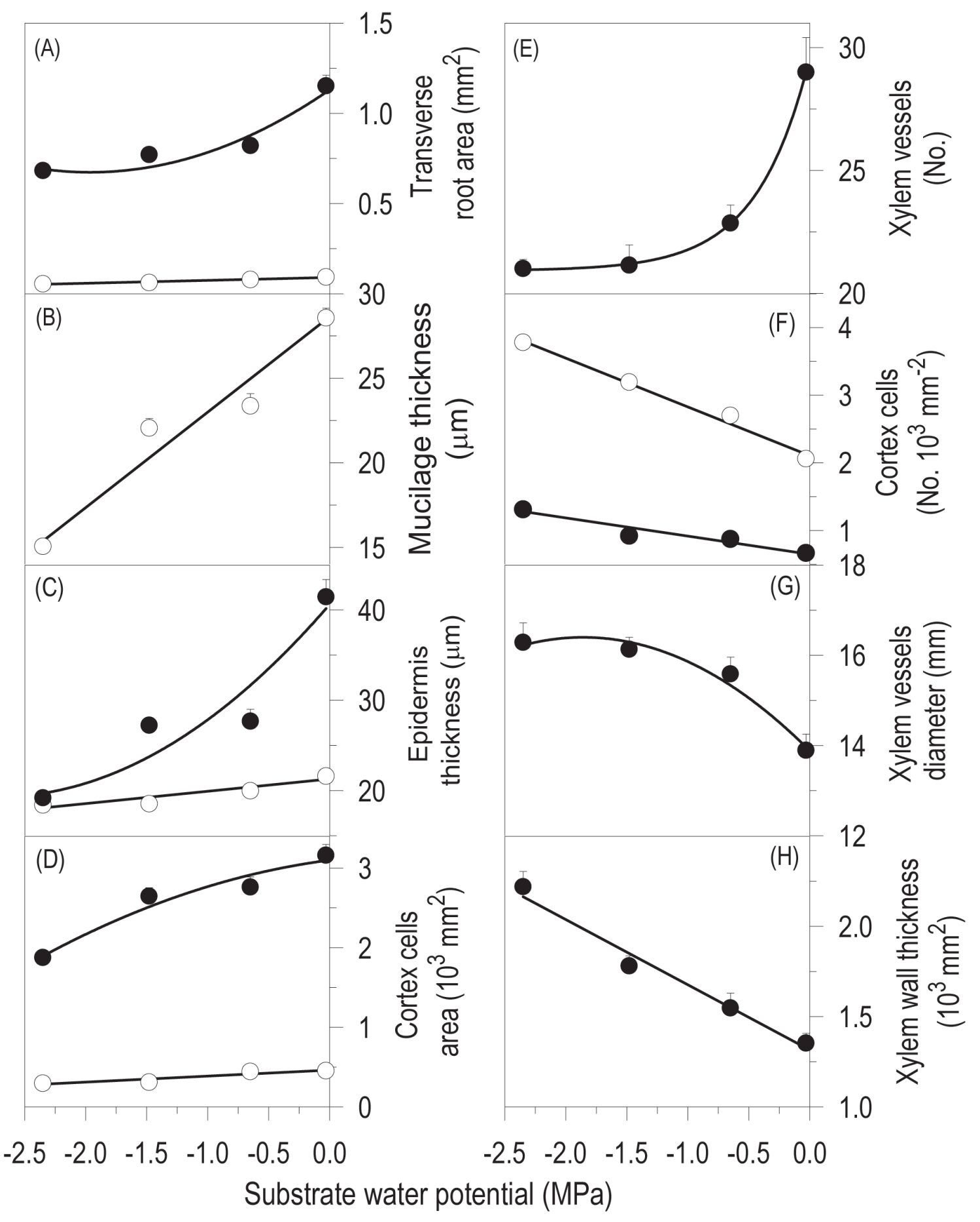

Figure 3: Effects of substrate water potential in the anatomy of root seedlings of Agave salmiana Otto ex Salm-Dyck. Cell division $(O)$ and differentiation $(\bullet)$ root region. Each point represents the average of four root cross section replicates $(n=7$ and 50, respectively) + standard error. 
that observed in "maguey". Epidermis thickness, cell area of cortex, and number of xylem vessels diminished, and the number of cortex cells and the xylem wall thickness increased in root cross sections of maize seedlings (Tux. Seq. C0 and Tux. Seq. C8 cultivars, drought sensitive and drought tolerant, respectively) growing in a substrate at $\Psi_{\mathrm{W}}$ lower than $-0.03 \mathrm{MPa}$ (Peña-Valdivia et al., 2005). These results suggest that some anatomical root changes are independent of plant species and essential for growing seedlings under low $\Psi_{\mathrm{W}}$.

In contrast, substrate with low $\Psi_{\mathrm{W}}$ seems to affect some other characteristics depending on the cultivar, species or intrinsic plant drought tolerance. This is the case of mucilage thickness, which increased 44 and $50 \%$ in maize root seedlings of Tux. Seq. C0 and Tux. Seq. C8, respectively, growing at $-2.35 \mathrm{MPa}$ (PeñaValdivia et al., 2005), but mucilage thickness in maguey diminished $46 \%$ in the same substrate $\Psi_{\mathrm{W}}$ (Fig. 3 B). Another case is xylem vessel diameter, which increased 15 and $16 \%$ in Tux. Seq. C8 maize (PeñaValdivia et al., 2005) and maguey (Fig. 3B) root seedlings growing at $-2.35 \mathrm{MPa}$; but, a $10 \%$ reduction in xylem vessels diameter was observed in maize (cv. Tux. Seq. C0) drought sensitive (Peña-Valdivia et al., 2005).

It should be stressed that under experimental conditions, in the present study adventitious roots were absent in maguey seedlings; in contrast, PeñaValdivia et al. (2005) found in maize Tux. Seq. C0 (drought sensitive) after $72 \mathrm{~h}$ of germination a significantly higher number of adventitious roots than in Tux. Seq. C8 (drought tolerant) (3.3 and 2.8 adventitious roots per seedling, respectively); besides, only in Tux. Seq. C8, the number of adventitious roots diminished with the $\Psi_{\mathrm{W}}$ of vermiculite, up to $23 \%$ at $-2.35 \mathrm{MPa}$. North and Nobel (1995) showed that xylem vessel dimensions in young roots, as well in lateral roots of $A$. deserti, changed when plants were growing under water deficit ( 7 to $30 \mathrm{~d}$ ), and these changes were apparently related to a reduction of root conductivity. Diameter of root structures involved in water conduction increased significantly in A. salmiana seedlings growing under low substrate $\Psi_{\mathrm{w}}$ (Fig. $3 \mathrm{G}$ ).

Apoplastic and symplastic root barriers for water and ion flows can develop during water stress. In the present study, wall thickness of xylem roots increase significantly with the lowest substrate $\Psi_{\mathrm{W}}$ (Fig. $3 \mathrm{H}$ ). But, when seedlings grew with the highest $\Psi_{\mathrm{W}}(-0.03 \mathrm{MPa})$, the xylem vessel number, diameter of xylem vessel and its wall thickness did not correlate significantly with any other studied variable of root growth. Maize root thinning was accompanied by an increase of anticlinal cellular division, equivalent to an increase by $35 \%$ of the number of cells in the cortex, when substrate $\Psi_{\mathrm{W}}$ is $-1.61 \mathrm{MPa}$ (Liang et al., 1997). Root seedlings of Agave salmiana at $\Psi_{\mathrm{W}}$ of $-2.35 \mathrm{MPa}$ were thinner (Fig. $3 \mathrm{~A}$ ), the number of cortex cells significantly increases (Fig. 3 F) and this variable is negatively correlated with the transverse root area in both differentiation and elongation root regions $(\mathrm{r}=-0.363$ and $-0.661, \mathrm{P}=0.016$ and $<0.001$, $\mathrm{n}=44$ and 32 , respectively). The meaning of the increase of transverse root cells as a reaction to water deficit is unclear; it seems that root cells probably lose water at the lower substrate water potentials, thereby shrinking, and thus cell number per square millimetre increased. According to Liang et al. (1997) a large number of cells increase the total root area including more apoplatic paths and water and ion movement into the root.

The results of the present study demonstrate that Agave salmiana seedlings represent a good model for studying the effect of substrate $\Psi_{\mathrm{W}}$ on root growth, tissue composition and anatomical changes with minimum effects of the undeveloped shoot. The "maguey" seedlings clearly react in several ways like the common bean and maize seedlings to substrate $\Psi_{\mathrm{W}}$ and in contrast in some ways differently (PeñaValdivia, 2005; Sánchez-Urdaneta et al., 2004 and 2005). However, it is necessary to continue studying and including more species to contrast diverse plant models to confirm the "maguey" reaction to low substrate $\Psi_{\mathrm{W}}$ more clearly 


\section{CONCLUSIONS}

Root of maguey seedlings express detectable changes in growth as a reaction to low substrate $\Psi_{\mathrm{W}}$ for short periods of time $(24 \mathrm{~h})$ and these changes are a result of physiological, biophysical and anatomical modifications. Proline seems to be an osmoregulator for maintaining root growth at low substrate $\Psi_{\mathrm{W}}$; the anatomical changes associated with low $\Psi_{\mathrm{W}}$ are evidence of an increase of apoplatic paths. As well, maguey root seedling structures involved in water conduction increased their diameter significantly under low substrate $\Psi_{\mathrm{W}}$ conditions.

\section{ACKNOWLEDGEMENT}

We appreciate the proof-reading of Dr. Rodolfo García N.

\section{REFERENCES}

ALBARRÁN R AE (2004) Efectos de la Restricción de Humedad en la Fisiología, Crecimiento, Componentes del Rendimiento y Calidad del Grano de Centeno (Secale cereale L.) y Trigo (Triticum aestivum L.). Tesis de maestría. Colegio de Postgraduados, Montecillo, México

ASSENG S, RITCHIE JT, SMUCKER AJM, ROBERTSON MJ (1998) Root growth and water uptake during water deficit and recovering in wheat. Plant Soil 201: 265-273

BACELAR EA, MOUTINHO-PEREIRA JM, GONÇALVES BC, FERREIRA HF, CORREIA CM (2007) Changes in growth, gas exchange, xylem hydraulic properties and water use efficiency of three olive cultivars under contrasting water availability regimes. Environ Exp Bot 60: 183-192

BATES LW, WALDREN RP, TEARE LD (1973) Rapid determination of proline for water stress studies. Plant Soil 39: 205-207

BOBICH EG, GRETCHEN BN (2009) Structural implications of succulence: architecture, anatomy, and mechanics of photosynthetic stem succulents, pachycauls, and leaf succulents. In: Perspectives in Biophysical Plant Ecophysiology. Edited by De la Barre, Smith WK. Universidad Nacional Autónoma de México. México

DAVIES WJ, ZHANG J (1991) Root signals and the regulation of growth and development of plants in drying soil. Annu Rev Plant Physiol Plant Mol Biol 42: $55-76$

DUBROVSKY JG (1997) Determinate primary-root growth in seedlings of Sonora Desert Cactaceae; its organization, cellular basis, and ecological significance. Planta 203: 85-92

ELLIS RH, HONG TD, ROBERTS EH (1985) General approaches to promoting seed germination. In
Handbook of seed technology for genebanks. Vol. II. Compendium of specific germination. International Board for Plant Genetic Resources, Rome, pp. 221-237

FACETTE MR, MCCULLY ME, CANNY MJ (1999) Response of maize roots to drying-limits of viability Plant Cell Environ 22: 1559-1568

GARCÍA E (1988) Modificaciones al Sistema de Clasificación Climática de Köppen. UNAM. México

GIBSON AC, NOBEL PS (1986) The cactus primer. Harvard University Press. Cambridge, Massachusetts

HARE PD, CRESS WA (1997) Metabolic implications of stress-induced proline accumulation in plants. Plant Growth Regul 21: 79-102

HUANG B, GAO H (2000) Root physiological characteristics associated with drought resistance in tall fescue cultivars. Crop Sci 40: 196-203

KHADRI M, TEJERA NA, LLUCH C (2007) Sodium chloride-ABA interaction in two common bean (Phaseolus vulgaris) cultivars differing in salinity tolerance. Environ Exp Bot 60: 211-218

KOIKE T, KITAO M, QUORESHI AM, MATSUURA Y (2003) Growth characteristics of root-shoot relations of three birch seedlings raised under different water regimes. Plant Soil 255: 303-310

LIANG BM, SHARP RE, BASKIN TI (1997) Regulation of growth anisotropy in well-watered and waterstressed maize roots. I. Spatial distribution of longitudinal, radial, and tangential expansion rates. Plant Physiol 115: 101-111

NOBEL PS, SCHULTE J, NORTH GB (1990) Water influx characteristics and hydraulic conductivity for roots of Agave deserti Engelm. J Exp Bot 41: 409-415

NORTH GB, NOBEL PS (1995) Hydraulic conductivity of concentric root tissues of Agave desertii Engelm. under wet and drying conditions. New Phytol 130: 47-57

PASSIOURA JB (2002) Soil conditions and plant growth. Plant Cell Environ 25: 311-318

PEÑA-VALDIVIA CB, SÁNCHEZ-URDANETA AB, TREJO C, AGUIRRE RJR, CÁRDENAS E (2005) Root anatomy of drought sensitive and tolerant maize (Zea mays L.) seedlings under different water potentials. Cereal Res Commun 33: 705-712

PEÑA-VALDIVIA CB, SÁNCHEZ-URDANETA AB, AGUIRRE RAR, TREJO C, CÁRDENAS E, VILLEGAS MA (2006) Temperature and mechanical scarification on seed germination of "maguey" (Agave salmiana Otto ex Salm-Dyck). Seed Sci Tech 34: 47-56

PRECHAMANDRA GS, SANEORA H, FUJITA K, OGATA S (1992) Osmotic adjustment and stomatal response to water deficit in maize. J Exp Bot 43: 14511456

RAYMOND MJ, SMIRNOFF N (2002) Proline metabolism and transport in maize seedlings at low water potential. Ann Bot 89: 813-823

SAITO T, TERASHIMA I (2004) Reversible decreases in the bulk elastic modulus of mature leaves of deciduous Quercus species subjected to two drought treatments. Plant Cell Environ 27: 863-875

SÁNCHEZ UAB (2000) Fertilización foliar nitrogenada y anillado en la tasa fotosintética de tres selecciones de durazno (Prunus persica (L.) Batsch) y su relación con diferenciación floral. Tesis de maestría. Colegio de Postgraduados. Montecillo, México

SÁNCHEZ-URDANETA AB, PEÑA-VALDIVIA CB, TREJO C, AGUIRRE RJR, CÁRDENAS E, GALICIA JA (2003) Permeabilidad de las membranas radicales de plántulas de frijol (Phaseolus vulgaris L.) silvestre y domesticado bajo déficit de humedad. Interciencia 28: 597-603

SÁNCHEZ-URDANETA AB, PEÑA-VALDIVIA CB, 
TREJO C, AGUIRRE RJR, CÁRDENAS E, GALICIA JA (2004) Efectos del potencial de agua en el crecimiento de la raíz de plántulas de frijol (Phaseolus vulgaris L.) silvestre y domesticado. Acta Científica Potosina 16: 18-42

SÁNCHEZ UAB, PEÑA-VALDIVIA CB, TREJO C, AGUIRRE RJR, CÁRDENAS E (2005) Root growth and proline content of drought sensitive and tolerant maize (Zea mays L.) under different water potential. Cereal Res Commun 33: 697-704

SHARP RE, SILK WK, HSIAO TC (1988) Growth of the maize primary root at low water potentials. I. Spatial distribution of expansive growth. Plant Physiol 87: 5057

SHARP RE, HSIAO TC, SILK WK (1990) Growth of the maize primary root at low water potentials. II. Role of growth and deposition of hexose and potassium in osmotic adlustment. Plant Physiol 93: 1337-1348

SHARP RE, POROYKO V, HEJLEK LG, SPOLLEN WG, SPRINGER GK, BOHNERT HJ, NGUYEN, HT (2004) Root growth maintenance during water deficits: physiology to functional genomics. J Exp Bot 55: 2343-2351

SMITH SM, SNEDAKER, SC (2000) Hypocotyl Function in Seedling Development of the Red Mangrove, Rhizophora mangle L. Biotropica 32: 677-685

SOFO A, DICHIO B, XILOYANNIS C, MASIA A (2004) Lipoxygenase activity and proline accumulation in leaves and roots of olive trees in response to drought stress. Physiol Plantarum 121: 58-65

SPOLLEN WG, SHARP RE, SAAB IN, WU Y (1993) Regulation of cell expansion in roots and shoots at low water potentials. In: Water Deficits. Edited by Smith JAC, Griffiths H. Scientific Publishers. USA

STEUDLE E (2000) Water uptake by roots: effect of water deficit. J Exp Bot 51: 1531-1542

TOUCHETTE BW (2006) Salt tolerance in a Juncus roemerianus brackish marsh: spatial variations in plant-water relations. J Exp Mar Biol Ecol 337: 1-12

UMAYAL L, BABU RC, CHEZHIAN P, SADASIVAM S (2001) Water stress induced histological and enzymatic changes in roots of rice cultivars. Plant Archives 1: 31 34

VICRÉ M, FARRANT JM, DRIOUICH A (2004) Insights into the cellular mechanisms of desiccation tolerance among angiosperm resurrection plant species. Plant Cell Environ 27: 1329-1340

WILCOX D, DOVE B, MCDAVID D, GREER D (2002) Image Tool for Windows. Version 3.0. The University of Texas Health Science Center. San Antonio, Texas

WU Y, COSGROVE DJ (2000) Adaptation of roots to low water potentials by changes in cell wall extensibility and cell wall proteins. J Exp Bot 51: 1543

XINGYUAN Z, FULIANG C, GUOHUA L (2004) Physiological responses of two warm-season turfgrasses to persistent soil drought stress. Acta Prataculturae Sinica 13: 84-88

YIN C, DUAN B, WANG X, LI C (2004) Morphological and physiological responses of two contrasting poplar species to drought stress and exogenous abscisic acid application. Plant Sci 167: 1091-1097

ZLATEV ZS (2005) Effects of water stress on leaf water relations of young bean plants. J Cent Eur Agric 6: 514 